\title{
Molecular Characterization of Antimicrobial Resistance and Virulence Genes of Bacterial Pathogens from Bovine and Caprine Mastitis in Northern Lebanon
}

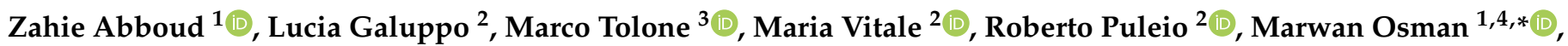 \\ Guido Ruggero Loria ${ }^{2, *}$ and Monzer Hamze ${ }^{1, *}$ \\ 1 Laboratoire Microbiologie Santé et Environnement, Doctoral School of Sciences and Technology, \\ Faculty of Public Health, Lebanese University, Tripoli P.O. Box 146404, Lebanon; zahie.abboud1@gmail.com \\ 2 Istituto Zooprofilattico Sperimentale della Sicilia, Via G. Marinuzzi 3, 90129 Palermo, Italy; \\ galuppolucia@gmail.com (L.G.); maria.vitale@izssicilia.it (M.V.); roberto.puleio@izssicilia.it (R.P.) \\ 3 Dipartimento di Scienze Agrarie, Alimentari e Forestali, University of Palermo, Viale delle Scienze, \\ 90128 Palermo, Italy; marco.tolone@unipa.it \\ 4 Department of Population Medicine and Diagnostic Sciences, College of Veterinary Medicine, \\ Cornell University, Ithaca, NY 14850, USA \\ * Correspondence: mo368@cornell.edu (M.O.); guidoruggero.loria@izssicilia.it (G.R.L.); \\ mhamze@monzerhamze.com (M.H.)
}

Citation: Abboud, Z.; Galuppo, L.; Tolone, M.; Vitale, M.; Puleio, R.; Osman, M.; Loria, G.R.; Hamze, M. Molecular Characterization of Antimicrobial Resistance and Virulence Genes of Bacterial Pathogens from Bovine and Caprine Mastitis in Northern Lebanon. Microorganisms 2021, 9, 1148. https://doi.org/ 10.3390/microorganisms 9061148

Academic Editors: Thierry Naas, Rémy A. Bonnin and Laura Dabos

Received: 29 April 2021

Accepted: 18 May 2021

Published: 27 May 2021

Publisher's Note: MDPI stays neutral with regard to jurisdictional claims in published maps and institutional affiliations.

Copyright: (c) 2021 by the authors Licensee MDPI, Basel, Switzerland. This article is an open access article distributed under the terms and conditions of the Creative Commons Attribution (CC BY) license (https:/ / creativecommons.org/licenses/by/ $4.0 /)$.

\begin{abstract}
Mastitis is an infectious disease encountered in dairy animals worldwide that is currently a growing concern in Lebanon. This study aimed at investigating the etiology of the main mastitiscausing pathogens in Northern Lebanon, determining their antimicrobial susceptibility profiles, and identifying their antimicrobial resistance (AMR) genes. A total of 101 quarter milk samples were collected from 77 cows and 11 goats presenting symptoms of mastitis on 45 dairy farms. Bacterial identification was carried out through matrix-assisted laser desorption/ionization-time of flight mass spectrometry. Antimicrobial susceptibility was tested by disc diffusion and broth microdilution methods. Molecular characterization included polymerase chain reaction (PCR) screening for genes encoding extended-spectrum beta-lactamases (ESBLs) and plasmid-mediated AmpC among Enterobacterales isolates, and virulence factors among Staphylococcus isolates. Escherichia coli isolates were subjected to phylogenetic typing by a quadruplex PCR method. The most frequently identified species were Streptococcus uberis (19.2\%), Streptococcus agalactiae (15.1\%), E. coli (12.3\%), and Staphylococcus aureus (10.96\%). Gram-positive bacteria were resistant to macrolides and tetracycline, whereas gram-negative bacteria displayed resistance to ampicillin and tetracycline. Two ESBL genes, $b l a_{\mathrm{TEM}}$ $(83.3 \%)$ and $b l a_{\mathrm{OXA}}(16.7 \%)$, and one $A m p C$ beta-lactamase gene, bla $\mathrm{CMY}$-II $(16.7 \%)$, were detected among six E. coli isolates, which mainly belonged to phylogenetic group B1. Among Staphylococcus spp., the mecA gene was present in three isolates. Furthermore, four isolates contained at least one toxin gene, and all $S$. aureus isolates carried the ica operon. These findings revealed the alarming risk of AMR in the Lebanese dairy chain and the importance of monitoring antimicrobial usage.
\end{abstract}

Keywords: mastitis; antimicrobial resistance; molecular epidemiology; beta-lactamase; one health; virulence; biofilm; Lebanon

\section{Introduction}

Mastitis is by far the most widespread and costly disease in dairy cattle worldwide. It has severe and significant economic consequences that include losses in milk production, adverse health effects, early, mandatory culling, costly veterinary services, and additional labor for animal care costs [1-3]. It is a well-established disease that affects a high percentage of dairy cows and is of particular concern for farmers in both developed and developing countries [4,5]. Goat farms also suffer economic losses when faced with the burden of mastitis, which is mainly caused by staphylococcal intramammary infections [6,7]. 
North Lebanon is home to extensive dairy farming and production of milk and its derivatives, which constitute a fundamental part of the Mediterranean diet. Dairy products are consumed daily by different age categories. The dairy sector in Lebanon is also of important economic significance. It represents a leading source of income for producers and families in rural communities, as well as a beneficial opportunity for labor. Approximately $60 \%$ of livestock farmers rely on dairy as their main source of income [8]. The development of the dairy sector in Lebanon has led to excessive use of antimicrobials to improve animal health by treating clinical signs of infectious diseases, such as mastitis, and therefore increase their productivity [9]. Several antimicrobial compounds are also currently used as growth promoters in animal production [10].

Mastitis was reported as the most common cause for antimicrobial administration in farming [11]. Because it is so widespread, mastitis is a concerning issue in Lebanon, especially since local farmers and even veterinarians treat infected animals without the necessary support from laboratory services. Conventional antimicrobials used for mastitis therapy are consequently showing reduced effectiveness in dairy cattle. The prolonged misusage of antimicrobial compounds for the treatment of mastitis has contributed to the emergence of antimicrobial resistance (AMR) [12].

Unfortunately, there is neither enough data on the distribution and circulation of pathogens involved in mastitis and their susceptibility patterns to antimicrobials nor on antimicrobial usage in livestock treatment in Lebanon. However, the limited available reports showed high levels of coliform bacteria contamination in traditional Lebanese dairy products and many of these isolates are associated with multi-drug resistance patterns $[13,14]$. A cross-sectional study also indicated that $27.9 \%$ of raw milk samples in Lebanon are contaminated with extended-spectrum beta-lactamase (ESBL)- and/or carbapenemase-producing Enterobacterales [14]. Moreover, a high prevalence of ESBLproducing Escherichia coli isolates (67.5\%) was reported among healthy cattle as well as a remarkable prevalence of ESBL-positive cattle farms (84\%) [15]. Similarly, Zouhairi and colleagues stated that $98.7 \%$ of Staphylococcus isolates from Lebanese dairy-based food products were resistant to at least one antimicrobial drug, with $94 \%$ being methicillinresistant [16]. Indeed, contaminated dairy products may harbor these antimicrobial resistant microorganisms and may pose a threat to public health by acting as vehicles of transmission of these pathogens, which will later be responsible for food-borne diseases. On the other hand, a recent investigation showed the poor knowledge and irresponsibility of the Lebanese population regarding antimicrobial misuse and resistance [17]. What makes the situation more alarming is the wide availability of antimicrobials in the Lebanese market without the requirement of a veterinarian's prescription $[10,18,19]$.

In this context, the purpose of the current study was to isolate and identify the main pathogenic bacteria that cause clinical mastitis in dairy farms in Northern Lebanon and to determine their susceptibility patterns to the most frequent classes of antimicrobials utilized in veterinary management. This study also investigated the presence of genes related to AMR, and identified the phylogenetic groups of ESBL- and AmpC-positive Escherichia coli isolates. We also determined the mosaicism of specific virulence genes among Staphylococcus isolates.

\section{Materials and Methods}

\subsection{Survey Design}

A questionnaire-based survey was performed during March and April 2019 on 45 dairy farms located in the North of Lebanon. For each participating dairy farm, a record sheet registering general information about the farm and a short description of the herd (farm name or area/district, species, clinical signs, percentage of suspected animals, therapy history, and laboratory tests) was collected at the time of inclusion. 


\subsection{Sample Collection}

During March and April 2019, 101 mastitis milk samples (90 cow milk samples and 11 goat milk samples) were aseptically collected from 77 dairy cows and 11 goats showing symptoms of infectious mastitis. Multiple milk samples were at times collected from different quarters of the same cow. Samples were taken from a total of 45 dairy farms located in 32 villages in the Northern region of Lebanon. The villages in which the dairy farms are located are reported in Figure 1. Field veterinarians were responsible for milk sampling. The material supplied for aseptic sampling included disposable gloves and towels, alcohol, cotton, $15 \mathrm{~mL}$ sterile sampling tubes, and a specific record sheet for each milk sample. Briefly, teats were cleaned and disinfected using alcohol, the first three streams were discarded, and then milk samples were collected in sterile $15 \mathrm{~mL}$ conical tubes. The cooled milk samples were transported on the same day in iceboxes directly to the microbiology laboratory and then processed the same day.

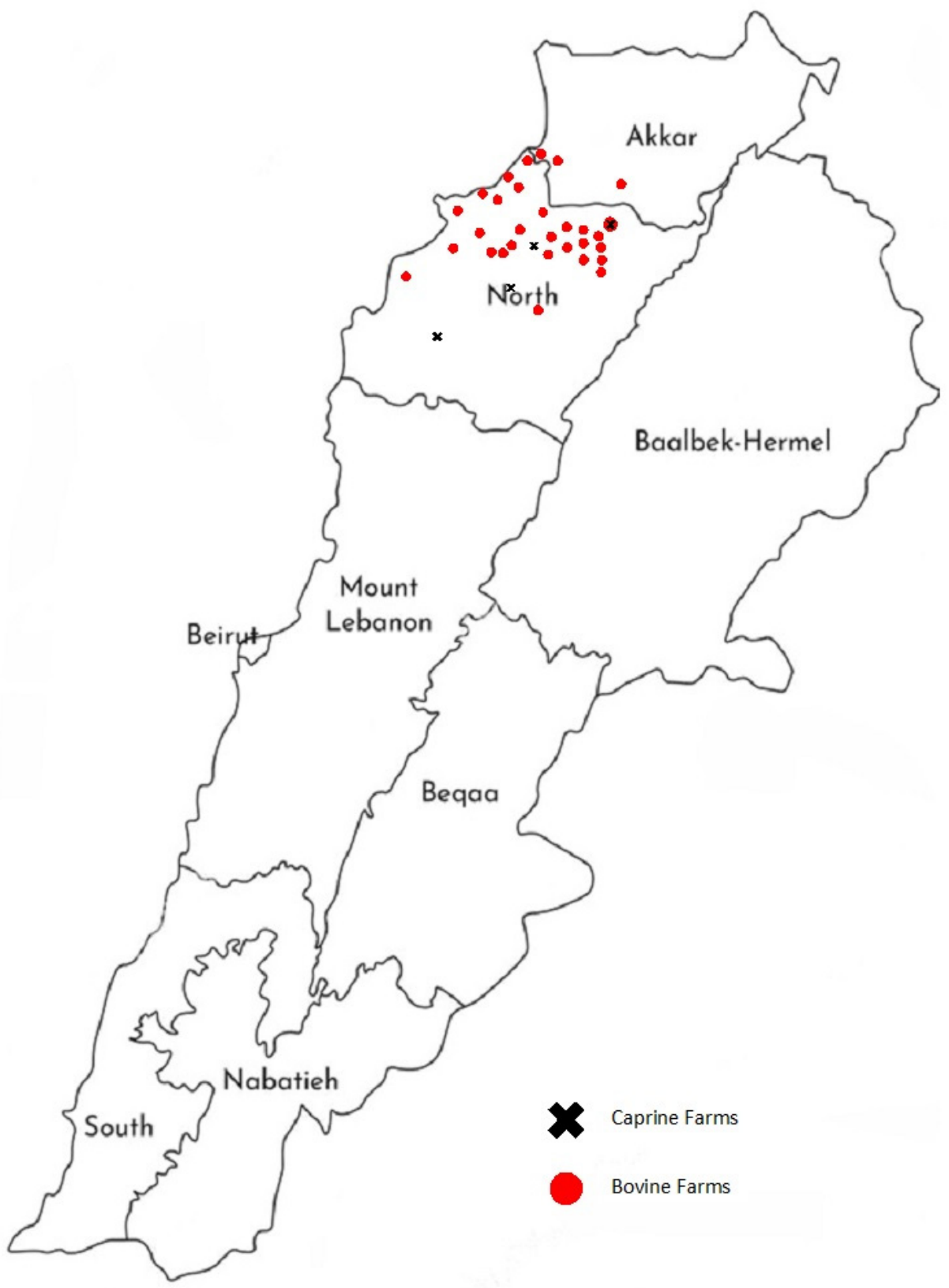

Figure 1. Map of Lebanon displaying the villages in which the dairy farms involved in this study are located. 


\subsection{Culturing Techniques and Species Identification}

Raw milk samples were examined microbiologically by plating $10 \mu \mathrm{L}$ of each sample on the following media: Columbia agar with 5\% blood; and Columbia CNA Agar with $5 \%$ blood, drigalski agar, and mannitol salt agar (all from BioRad, Marnes-la-Coquette, France). The plates were incubated at $37^{\circ} \mathrm{C}$ for $24-48 \mathrm{~h}$. Blood agar plates were incubated in $5 \% \mathrm{CO}_{2}$. The culture was considered positive if there was a growth of individual bacteria in a concentration of more than $10^{4} \mathrm{CFU} / \mathrm{mL}$. All isolates were identified and characterized by matrix-assisted laser desorption/ionization time-of-flight mass spectrometry (MALDI-TOF MS) using a VITEK MS instrument (bioMérieux, Marcy l’Etoile, France).

\subsection{Antimicrobial Susceptibility Testing}

According to the Clinical Laboratory Standard Institute (CLSI) recommendations, bacterial isolates were tested for their antimicrobial susceptibility by standard disk diffusion method either on Mueller-Hinton agar or Mueller-Hinton agar with 5\% blood added. The inhibition zones were measured, recorded, and interpreted according to the CLSI guidelines. Minimum inhibitory concentration (MIC) values for all isolates were determined using a broth microdilution method with 96-well microtitre plates (BOPO6, Sensititre, Trek Diagnostic Systems, East Grinstead, UK) containing a total of 18 antimicrobials. The 96-well antimicrobial susceptibility plate contained scaled dilutions for the following 18 antimicrobials: ceftiofur (XNL) (0.25-8), tiamulin (TIA) (0.5-32), chlortetracycline (CTET) $(0.5-8)$, gentamicin (GEN) (1-16), florfenicol (FFN) (0.25-8), oxytetracycline (OXY) (0.5-8), penicillin (PEN) (0.12-8), ampicillin (AMP) (0.25-16), danofloxacin (DANO) (0.12-1), Sulfadimethoxine (SDM) (256), Neomycin (NEO) (4-32), Trimethoprim/sulfamethoxazole (SXT) (2/38), spectinomycin (SPE) (8-64), tylosin tartrate (TYLT) (0.5-32), tulathromycin (TUL) (1-64), tilmicosin (TIL) (4-64), clindamycin (CLI) (0.25-16), and enrofloxacin (ENR) (0.12-2). The plates were incubated aerobically at $37^{\circ} \mathrm{C}$ for $24 \mathrm{~h}$ ( $48 \mathrm{~h}$ for Streptococcus spp.) and were read manually using the Thermo Scientific ${ }^{\mathrm{TM}}$ Sensititre ${ }^{\mathrm{TM}}$ Manual Viewbox.

\subsection{Detection of AMR Genes}

The primers and their sequences used in the PCRs are listed in Table S1 of the Supplementary Materials. DNA was extracted by a boiling technique. A loop of bacterial colonies was put in a test tube containing $1 \mathrm{~mL}$ of sterile $10 \mathrm{mM}$ TRIS $1 \mathrm{mM}$ EDTA (T.E) buffer $0.1 \%$ and heated in the Dry Bath (EuroClone, Milan, Italy) at $95^{\circ} \mathrm{C}$ for $30 \mathrm{~min}$. The solution was then centrifuged for five minutes at $1000 \mathrm{rpm}$. The supernatant was collected and used for the downstream process of PCR. Two multiplex PCR reactions were performed to amplify ESBL and AmpC beta-lactamase genes in E. coli and Klebsiella oxytoca isolates, as described by [20]. The first multiplex assay (named Set I) was designed to detect TEM, SHV, CTX-M IV group, and OXA beta-lactamase encoding genes, and the second assay (named Set II) was signed to detect CTX-M I group, CTX-M II group, CMY II, and DHA encoding genes. Additionally, Staphylococcus spp. oxacillin-resistant isolates were tested for the presence of the mecA and mecC genes for confirmation of methicillin resistance.

\subsection{Determination of Phylogenetic Groups}

The distribution of phylogenetic groups amongst ESBL- and/or AmpC-producing E. coli isolates was determined as described by Clermont and colleagues [21]. Eight phylogroups are now recognized: seven (A, B1, B2, C, D, E, F) belong to E. coli sensu stricto, whereas the eighth is the Escherichia cryptic clade I. Phylogenetic groups were identified by multiplex PCR based on the presence or absence of four DNA markers (chuA, yjaA, DNA fragment TSPE4.C2, and $\operatorname{arpA}$ ).

\subsection{Detection of Biofilm and Virulence Associated Genes of Staphylococcus Spp.}

The capability of Staphylococcus spp. to form biofilm is considered an additional virulence factor in mastitis cases, due to its ability to adhere to and persist in tissues and the environment [22]. Thus, two separate reactions of PCR were performed to amplify 
biofilm-associated protein (bap) and fragments of the intracellular adhesion (ica) genes involved in biofilm formation in Staphylococcus spp. as previously described [23]. Moreover, multiplex PCR assays were carried out to amplify staphylococcal enterotoxins (sea-see, seg, seh, sei, sej, and sep), exfoliative toxins (eta and etb), and toxic shock syndrome toxin 1 (tsst-1) genes, as recently described in [24].

\section{Results}

\subsection{Main Findings of the Questionnaire-Based Survey}

Our comprehensive questionnaire-based survey revealed that the most prevalent form of mastitis encountered in our study area was clinical mastitis $(92 \% ; 81 / 88)$, followed by subclinical mastitis $(8 \% ; 7 / 88)$. Animals had at least one of the following symptoms: abnormal milk appearance (presence of blood in milk and/or watery to viscous milk with clots varying from gray-white to yellowish) $(60.2 \%)$, hardness and swelling of the udder (47.7\%), and/or reduced milk production $(45.4 \%)$, inappetence $(3.4 \%)$, diarrhea $(2 \%)$, chronic inflammation $(1.1 \%)$, and/or anorexia (1.1\%). Empirical antimicrobial treatment was reported in four farms using cefaclor $\left(\right.$ Cefatek $\left.^{\circledR}\right)$, amoxicillin, tylosin, colistin, gentamicin $(10 \%$ intramuscular injection), and/or a combination of penicillin and kanamycin (Penikan $\mathrm{P}^{\circledR}$ ). No laboratory tests were performed before and after antimicrobial prescription, suggesting a potential misuse of drugs.

\subsection{Distribution of Pathogens}

In total, sixty-four milk samples $(63.4 \% ; 64 / 101)$ were positive by conventional culture. Out of these samples, 73 mastitis-causing pathogens were identified, of which 55 were grampositive bacteria $(75.3 \% ; 55 / 73)$ and 18 were gram-negative bacteria $(24.7 \% ; 18 / 73)$. After MALDI-TOF MS analysis, Streptococcus uberis was the predominant bacterial species, followed by Streptococcus agalactiae, E. coli, Staphylococcus aureus, and Trueperella pyogenes (Table 1).

Table 1. Bacterial isolates from clinical and subclinical bovine and caprine mastitis cases.

\begin{tabular}{|c|c|c|c|c|c|}
\hline \multirow[t]{2}{*}{ Bacterial Species } & \multicolumn{2}{|c|}{ Animal Origin } & \multicolumn{2}{|c|}{ Status of Infection } & \multirow[t]{2}{*}{ Percentage $(\%)$} \\
\hline & Cow & Goat & Clinical & Subclinical & \\
\hline Streptococcus uberis & 14 & & 14 & & 19.2 \\
\hline Streptococcus agalactiae & 11 & & 11 & & 15.1 \\
\hline Escherichia coli & 7 & 2 & 9 & & 12.3 \\
\hline Staphylococcus aureus & 7 & 1 & 8 & & 11 \\
\hline Trueperella pyogenes & 5 & 2 & 7 & & 9.6 \\
\hline Aerococcus viridans & 4 & & 4 & & 5.5 \\
\hline Raoultella ornithinolytica & 3 & & 3 & & 4.1 \\
\hline Streptococcus dysgalactiae & 2 & & 2 & & 2.7 \\
\hline Streptococcus pluranimalium & 1 & 1 & 1 & 1 & 2.7 \\
\hline Corynebacterium bovis & 2 & & & 2 & 2.7 \\
\hline Corynebacterium xerosis & 2 & & & 2 & 2.7 \\
\hline Pseudomonas aeruginosa & 2 & & 2 & & 2.7 \\
\hline Staphylococcus caprae & & 1 & & 1 & 1.4 \\
\hline Staphylococcus haemolyticus & & 1 & & 1 & 1.4 \\
\hline Pantoea agglomerans & 1 & & 1 & & 1.4 \\
\hline Pasteurella multocida & 1 & & 1 & & 1.4 \\
\hline Klebsiella oxytoca & 1 & & 1 & & 1.4 \\
\hline Serratia marcescens & 1 & & 1 & & 1.4 \\
\hline Streptococcus pneumoniae & 1 & & 1 & & 1.4 \\
\hline Total & 65 & 8 & 66 & 7 & $100 \%$ \\
\hline
\end{tabular}

\subsection{Antimicrobial Resistance}

Selected bacterial species were subjected to AMR studies by disk diffusion and/or MIC methods including E. coli, K. oxytoca, Pantoea agglomerans, Serratia marcescens, Raoultella ornithinolytica, Pseudomonas aeruginosa, S. aureus, Staphylococcus caprae, Staphylococcus 
haemolyticus, S. uberis, S. agalactiae, and Streptococcus dysgalactiae. According to the CLSI guidelines, we reported three antimicrobials (oxacillin, erythromycin, and chloramphenicol) tested by the disk diffusion method, and ten commonly used antimicrobials (penicillin, ampicillin, ceftiofur, gentamicin, clindamycin, oxytetracycline, chlortetracycline, florfenicol, enrofloxacin, and trimethoprim/sulfamethoxazole). Of the eight $S$. aureus isolates screened, two (25\%) were methicillin-resistant (MRSA). Moreover, the S. haemolyticus isolate was methicillin-resistant, but the $S$. caprae isolate was susceptible to methicillin. Regarding $E$. coli, all isolates were resistant to ampicillin, but only $11.1 \%$ to ceftiofur. Lower levels of resistance were observed among streptococcal isolates for ampicillin: S. uberis (28.6\%), S. agalactiae $(0 \%)$, and S. dysgalactiae $(0 \%)$. Nevertheless, S. agalactiae showed a high resistance rate against both oxytetracycline and chlortetracycline (100\%), followed by S. uberis (92.9\%) and S. dysgalactiae (50\%). Similar resistance rates were observed among E. coli isolates against chlortetracycline $(88.9 \%)$ and oxytetracycline $(77.8 \%)$. However, fortunately, lower resistance rates were reported for florfenicol (55.6\%), trimethoprim/sulfamethoxazole (44.4\%), enrofloxacin (22.2\%), gentamicin (11.1\%), and chloramphenicol (0\%). For S. aureus isolates, low percentages of resistance to both oxytetracycline and chlortetracycline $(12.5 \%)$, gentamicin $(12.5 \%)$, and enrofloxacin $(0 \%)$ were observed. The results of antibiotic resistance of mastitis bacterial pathogens are presented in Table 2. Furthermore, the results obtained showed the presence of seven (77.8\%) multidrug-resistant (MDR) E. coli out of nine tested isolates, four of which were resistant to three antibiotic classes, and three to five [25]. In addition, one S. aureus isolate (12.5\%) was MDR.

Table 2. Percentage of resistant Enterobacterales, Pseudomonas spp., Staphylococcus spp., and Streptococcus spp. isolates recovered from milk samples with bovine and caprine mastitis cases.

\begin{tabular}{|c|c|c|c|c|c|c|c|c|c|c|c|c|c|}
\hline & $\mathrm{N}$ & PEN $\ddagger$ & AMP $\ddagger$ & $\mathrm{XNL} \ddagger$ & GEN $\ddagger$ & ERY!! & CLI $\ddagger$ & OXY $\ddagger$ & СTET $\ddagger$ & CHL!! & FFN $\ddagger$ & ENR $\ddagger$ & sXT $\ddagger$ \\
\hline Escherichia coli & 9 & - & 100 & 11.1 & 11.1 & - & - & 77.8 & 88.9 & 0 & 55.6 & 22.2 & 44.4 \\
\hline Klebsiella oxytoca & 1 & - & 100 & 0 & 0 & - & - & 100 & 100 & 0 & 0 & 0 & 0 \\
\hline Pantoea agglomerans & 1 & - & 0 & 0 & 0 & - & - & 0 & 100 & 0 & 0 & 100 & 0 \\
\hline Serratia marcescens & 1 & - & 100 & 0 & 0 & - & - & 100 & 100 & 0 & 100 & 0 & 0 \\
\hline Raoultella ornithinolytica & 3 & - & 100 & 0 & 0 & - & - & 0 & 100 & 0 & 0 & 0 & 0 \\
\hline Pseudomonas aeruginosa & 2 & - & - & - & 0 & - & - & - & & - & - & 50 & - \\
\hline Staphylococcus aureus & 8 & 62.5 & 50 & - & 12.5 & 0 & 0 & 12.5 & 12.5 & 0 & - & 0 & 0 \\
\hline Staphylococcus caprae & 1 & 100 & 100 & - & 0 & 0 & 0 & 0 & 100 & 0 & - & 0 & 0 \\
\hline $\begin{array}{c}\text { Staphylococcus } \\
\text { haemolyticus }\end{array}$ & 1 & 100 & 100 & - & 0 & 0 & 0 & 100 & 100 & 0 & - & 0 & 0 \\
\hline Streptococcus uberis & 14 & 14.3 & 28.6 & 14.3 & - & 71.4 & 100 & 92.9 & 92.9 & 42.9 & - & 50 & 0 \\
\hline Streptococcus agalactiae & 10 & 0 & 0 & 0 & - & 81.8 & 100 & 100 & 100 & 18.2 & - & 100 & 0 \\
\hline Streptococcusdysgalactiae & 2 & 0 & 0 & 0 & - & 50 & 50 & 50 & 50 & 50 & - & 0 & 0 \\
\hline
\end{tabular}

$\ddagger$ Determined using the broth microdilution method; !" Determined using the disk diffusion method. PEN-penicillin; OXAoxacillin; AMP—ampicillin; XNL_ceftiofur; GEN—gentamicin; ERY—erythromycin; CLI—clindamycin; OXY—oxytetracycline; CTET_ chlortetracycline; CHL_chloramphenicol; FFN_florfenicol; ENR_enrofloxacin; SXT_trimethoprim/sulfamethoxazole.

\subsection{Molecular Characterization of Clinical Isolates}

Out of the E. coli isolates, five and one were positive for $b l a_{\mathrm{TEM}}$ and $b l a_{\mathrm{CMY}}$-II genes, respectively. One $b l a_{\text {TEM }}$ producing E. coli carried an additional bla $a_{\text {OXA }}$ gene. However, the K. oxytoca isolate did not harbor any ESBL or AmpC beta-lactamase encoding gene. Phylogrouping on beta-lactamase-producing $E$. coli isolates revealed the predominance of the phylogenetic group B1(4/6; 66.7\%), followed by B2 and D (1/6; each). On the other hand, methicillin resistance was confirmed by the detection of the mec $A$ gene among the three staphylococcal isolates resistant to oxacillin (two S. aureus and one S. haemolyticus). None of the isolates harbored the mecC gene.

This report also investigated the presence of adhesin genes and showed that $40 \%$ of staphylococcal isolates were positive for at least one of the classical enterotoxin genes, and two $S$. aureus isolates harbored one or more enterotoxin genes. One $S$. aureus isolate harbored simultaneously the toxic shock syndrome toxin 1 (tsst-1) and the sec enterotoxin gene. Regarding biofilm formation genes, all the tested isolates were negative for bap gene, but all the $S$. aureus isolates were icaA positive (Table 3). None of the isolates harbored the exfoliative toxin genes. 
Table 3. Distribution of genes among Staphylococcus spp. isolates.

\begin{tabular}{|c|c|c|c|c|}
\hline Isolate & Enterotoxins & $\begin{array}{l}\text { Exfoliative Toxins and Toxic } \\
\text { Shock Syndrome Toxin-1 }\end{array}$ & Methicillin Resistance & Biofilm Formation \\
\hline S. aureus AL 081 & & & mec $A$ & ica operon \\
\hline S. aureus AL 084 & sei, seg & & mecA & ica operon \\
\hline S. aureus AL 085 & & & & ica operon \\
\hline S. aureus AL 086 & & & & ica operon \\
\hline S. aureus AL 087 & & & & ica operon \\
\hline S. aureus AL 088 & & & & ica operon \\
\hline S. aureus AL 089 & $\sec$ & tsst-1 & & ica operon \\
\hline S. aureus AL 090 & & & & ica operon \\
\hline S. haemolyticus AL 091 & sea, sej, sep & & mecA & \\
\hline S. caprae AL 092 & seb & & & \\
\hline
\end{tabular}

\section{Discussion}

AMR is a growing concern in both human and veterinary medicine in Lebanon $[10,18,19]$. The extensive use of broad-spectrum antimicrobials in farm animals, the food industry, and in human and veterinary medicine, has led to the emergence of MDR organisms in humans, animals, and the environment $[9,14,15,18,26-28]$. The results of the present study revealed that most E. coli isolates tested were MDR. Traditional farming and poor hygiene husbandry, typical of Mediterranean countries including Lebanon, enable the quick spread of resistant micro-organisms, which represents a major challenge for developing countries, including Lebanon, as it severely affects the quantity, quality, and safety of animal and food production with significant economic and social consequences [9,10].

Bacterial infections are the predominant cause of bovine and caprine mastitis. In this study, we reported 88 cases of clinical and subclinical mastitis. Only $10 \%$ of farms admitted recent administration of antimicrobials. Although $90 \%$ of farms did not report the use of antimicrobials, a non-negligible proportion of farmers are not aware of the proper use of antimicrobials or their effects on animals and perform false practices, which are at the root of the spread of AMR $[9,10,17]$. Several antimicrobials are readily and legally available in the Lebanese market without the requirement of a veterinarian's prescription [10].

The analysis of bacterial isolates from bulk milk samples showed the predominance of gram-positive bacteria, particularly S. uberis, S. agalactiae, and S. aureus, followed by E. coli. The distribution of mastitis bacterial pathogens varies between different geographic areas and even countries. For example, S. aureus and coagulase-negative staphylococci (CNS) have been reported as the most common bovine mastitis in the Middle East, North Africa, and Europe [29-37]. In the same context, a large-scale epidemiological study conducted in Italy reported the predominance of S. agalactiae and S. aureus in dairy herds [38]. Moreover, studies performed in European Mediterranean countries highlighted a significant presence of E. coli and Staphylococcus spp. [39-42]. Moreover, a high incidence of E. coli was also observed among bovine mastitis in India and Taiwan [43,44]. In addition, one mastitis case of Streptococcus pneumoniae was documented. Pneumococcus is a commensal bacterium that normally colonizes the human nasopharyngeal cavity and is transmitted by droplets and aerosols either from infected patients or healthy carriers [45]. Although this species is rarely reported in mastitis, various epidemiological studies showed its high prevalence in the Lebanese community [46,47]. This allows us to speculate that there is a potential threat of contamination by handlers. Antimicrobial susceptibility testing showed a high percentage of resistance among most gram-positive and gram-negative isolates against both oxytetracycline and chlortetracycline. This is in line with a previous report which described that $98.4 \%$ of streptococcal isolates from dairy cows with mastitis in China were resistant to tetracycline [48]. In Lebanon, a similar percentage of resistance was observed. 
Most E. coli (82.5\%) isolated from healthy adult cattle showed tetracycline resistance [15]. Numerous veterinary infectious diseases among cattle are the most frequently treated with oxytetracyclines, explaining the high resistance rates observed in this study [49].

In contrast to streptococcal isolates, which showed very low susceptibility results to erythromycin and clindamycin, none of the staphylococcal isolates showed resistance to these antimicrobials. Although no similar previous study was found in Lebanon, our findings are consistent with similar data reported across the world [42,50,51]. In the human field in Lebanon, a recent cross-sectional study displayed the absence of macrolide and lincosamide resistance in both MRSA and methicillin-sensitive S. aureus (MSSA) isolates among food handlers [52]. However, previous Lebanese studies on group A streptococci human isolates showed lower resistance to erythromycin and clindamycin [53,54].

MRSA was isolated twice (25\%) in this study. This percentage is consistent with clinical human studies at the nationwide level showing a similar prevalence of this resistance pattern. A compilation of antimicrobial susceptibility data of $S$. aureus from a network of 13 Lebanese hospitals indicated that $28 \%$ were MRSA [55]. Moreover, a previous study conducted in the same geographic area reported that $23.8 \%$ of $S$. aureus isolates were MRSA [52]. However, MRSA prevalence in the present study is significantly higher than that of other countries such as Croatia [56] and Ukraine [57].

Regarding E. coli, $100 \%$ and $11.1 \%$ of isolates were resistant to ampicillin and ceftiofur, respectively. Despite this, only one isolate presented resistance to ceftiofur using the phenotypic method. Third-generation cephalosporins resistance was screened by two multiplex PCR reactions as described by [20]. Overall, 55.5\% of E. coli isolates were positive for ESBL and plasmid-mediated AmpC beta-lactamase genes: $b l a_{\mathrm{TEM}}, b l a_{\mathrm{CMY}-\mathrm{II}}$, and/or $b l a_{\mathrm{OXA}}$. Unfortunately, due to logistical reasons, this study did not evaluate the susceptibility of isolates to other third-generation cephalosporins such as cefotaxime, ceftriaxone, ceftazidime, and cefixime. This study confirmed that food animals and foodstuffs are a well-known reservoir of ESBL-producing E. coli in Lebanon. Wide dissemination of third-generation cephalosporin resistance, coupled with resistances to carbapenems, colistin, and numerous other antimicrobial compounds, has been reported among animals in the last decade $[9,14,15,18,58]$. The phylogenetic typing analysis carried out on the ESBL-producing E. coli isolates revealed that most of them belong to phylogroups B1 $(66.7 \%)$ followed by both B2 and D (16.7\% each), which have previously been reported in clinical third-generation cephalosporin-resistant isolates in Lebanon [19]. Phylogenetic grouping is an important approach to understanding the pathogenicity and evolutionary relationships between different strains [59]. No association was identified between AMR and phylogroup due to the limited number of $E$. coli isolates. Thus, a larger study on a higher number of isolates is needed. At the worldwide level, the majority of E. coli mastitis strains belong to phylogenetic groups A and B1 [60]. A high frequency of phylogroup B1 was also observed in an Iranian study evaluating the phylogeny of $E$. coli isolated from clinical mastitis [61]. A Brazilian study revealed that most E. coli isolates from bovine mastitis belonged to phylogenetic group A (52\%), followed by B1 (38\%) [62]. Similarly, other studies from Ireland, Switzerland, Serbia, and China have noted that E. coli isolates were mainly assigned to the phylogenetic groups A and B1 [63-67].

The ability of $S$. aureus isolates to form biofilms is an important mechanism that reinforces pathogenicity and contributes to AMR. PCR results showed that all S. aureus isolates were positive for the intracellular adhesion gene icaA, while the bap gene was not identified in any of the isolates. Our findings follow previous studies conducted in Poland [68], New Zealand [22], and the United Kingdom [69] that detected the unique presence of the icaA gene among all $S$. aureus isolates from bovine mastitis. Our study also showed that $40 \%$ and $25 \%$ of staphylococcal and S. aureus isolates were positive for at least one enterotoxin gene, respectively. Interestingly, one S. aureus isolate simultaneously harbored tsst- 1 and sec genes, predicting the presence of the staphylococcal pathogenicity island 1 (SaPI1), as described previously [70]. 


\section{Conclusions}

This study provides a consistent source of relevant data on AMR levels and trends of mastitis bacterial pathogens in Lebanese dairy bovines and caprines. Despite resistance rate variations, our findings confirmed the wide dissemination of antimicrobial-resistant bacteria in the Lebanese dairy industry. Many causative agents isolated in this study are zoonotic and can be transmitted directly between animals and humans or through the food chain. Therefore, there is a drastic need for a national strategy based on the one health approach to address the AMR issue and regulate the usage of antimicrobials in the veterinary sector in Lebanon, including bans on over-the-counter drugs and growth promoters. Additionally, the training and education of farmers is necessary to create awareness of AMR through effective communication, education, and training. Further large-scale, nationwide studies are also needed to evaluate the correlations between the use of antimicrobials in common husbandry practices and the onset of AMR in Lebanon.

Supplementary Materials: The following are available online at https:/ / www.mdpi.com/article/10 .3390 / microorganisms9061148/s1, Table S1-Primer sequences used in PCRs.

Author Contributions: Conceptualization, G.R.L. and Z.A.; methodology, G.R.L. and M.H.; software, M.T.; validation, M.T.; investigation, R.P., L.G. and M.V.; writing-original draft preparation, M.O. and Z.A.; writing-review and editing, M.T. and M.O.; visualization, M.T.; supervision, M.H. All authors have read and agreed to the published version of the manuscript.

Funding: This research was funded by the Doctoral School of Sciences and Technology of the Lebanese University, Tripoli-Lebanon, and by the Italian Ministry of Health-Ricerca Corrente IZS (SI 04/2018).

Institutional Review Board Statement: The study was conducted according to the guidelines of the Declaration of Helsinki and approved by the Azm Center/Lebanese University ethical committee (document CE-EDST-3-2018), authorized by the Lebanese Ministry of Public Health.

Acknowledgments: The authors would like to thank the veterinarians Karim Mesto, Omar El Rahi, and Sanaa El Jundi, who assisted in the field collections, and Asmaa Alloush and Taha Abdou at the LMSE (Tripoli, Lebanon) for their technical assistance.

Conflicts of Interest: The authors declare no conflict of interest.

\section{References}

1. Banos, G.; Bramis, G.; Bush, S.J.; Clark, E.L.; McCulloch, M.E.B.; Smith, J.; Schulze, G.; Arsenos, G.; Hume, D.A.; Psifidi, A. The genomic architecture of mastitis resistance in dairy sheep. BMC Genom. 2017, 18. [CrossRef] [PubMed]

2. Aghamohammadi, M.; Haine, D.; Kelton, D.F.; Barkema, H.W.; Hogeveen, H.; Keefe, G.P.; Dufour, S. Herd-Level mastitisassociated costs on canadian dairy farms. Front. Vet. Sci. 2018, 5. [CrossRef]

3. Benić, M.; Maćešić, N.; Cvetnić, L.; Habrun, B.; Cvetnić, Ž.; Turk, R.; Đuričić, D.; Lojkić, M.; Dobranić, V.; Valpotić, H.; et al. Bovine mastitis: A persistent and evolving problem requiring novel approaches for its control—A review. Vet. Arh. 2018, 88, 535-557. [CrossRef]

4. Mekonnen, S.A.; Koop, G.; Lam, T.J.G.M.; Hogeveen, H. The intention of North-Western Ethiopian dairy farmers to control mastitis. PLOS ONE 2017, 12. [CrossRef]

5. Oliver, S.P.; Murinda, S.E. Antimicrobial resistance of mastitis pathogens. Vet. Clin. N. Am. Food Anim. Pract. 2012, 28, 165-185. [CrossRef]

6. $\quad$ Lima, M.C.; de Barros, M.; Scatamburlo, T.M.; Polveiro, R.C.; de Castro, L.K.; Guimarães, S.H.S.; da Costa, S.L.; da Costa, M.M.; Moreira, M.A.S. Profiles of Staphyloccocus aureus isolated from goat persistent mastitis before and after treatment with enrofloxacin. BMC Microbiol. 2020, 20. [CrossRef]

7. Merz, A.; Stephan, R.; Johler, S. Staphylococcus aureus isolates from goat and sheep milk seem to be closely related and differ from isolates detected from bovine milk. Front. Microbiol. 2016, 7. [CrossRef]

8. Food and Agriculture Organization. Recovery and Rehabilitation of the Dairy Sector in Lebanon. 2016. Available online: http:/ / www.fao.org/3/i5745e/i5745e.pdf (accessed on 29 April 2021).

9. Osman, M.; Al Mir, H.; Rafei, R.; Dabboussi, F.; Madec, J.-Y.; Haenni, M.; Hamze, M. Epidemiology of antimicrobial resistance in Lebanese extra-hospital settings: An overview. J. Glob. Antimicrob. Resist. 2019, 17, 123-129. [CrossRef]

10. Kassem, I.I.; Hijazi, M.A.; Saab, R. On a collision course: The availability and use of colistin-containing drugs in human therapeutics and food-animal farming in Lebanon. J. Glob. Antimicrob. Resist. 2019, 16, 162-164. [CrossRef] 
11. Higham, L.E.; Deakin, A.; Tivey, E.; Porteus, V.; Ridgway, S.; Rayner, A.C. A survey of dairy cow farmers in the United Kingdom: Knowledge, attitudes and practices surrounding antimicrobial use and resistance. Vet. Rec. 2018, 183, 746. [CrossRef]

12. Palma, E.; Tilocca, B.; Roncada, P. Antimicrobial resistance in veterinary medicine: An overview. Int. J. Mol. Sci. 2020, 21, 1914. [CrossRef] [PubMed]

13. Saleh, I.; Zouhairi, O.; Alwan, N.; Hawi, A.; Barbour, E.; Harakeh, S. Antimicrobial resistance and pathogenicity of Escherichia coli isolated from common dairy products in the Lebanon. Ann. Trop. Med. Parasitol. 2009, 103, 39-52. [CrossRef] [PubMed]

14. Diab, M.; Hamze, M.; Bonnet, R.; Saras, E.; Madec, J.Y.; Haenni, M. OXA-48 and CTX-M-15 extended-spectrum betalactamases in raw milk in Lebanon: Epidemic spread of dominant Klebsiella pneumoniae clones. J. Med. Microbiol. 2017, 66, 1688-1691. [CrossRef] [PubMed]

15. Diab, M.; Hamze, M.; Madec, J.-Y.; Haenni, M. High Prevalence of Non-ST131 CTX-M-15-Producing Escherichia coli in healthy cattle in Lebanon. Microb. Drug. Resist. 2017, 23, 261-266. [CrossRef]

16. Zouhairi, O.; Saleh, I.; Alwan, N.; Toufeili, I.; Barbour, E.; Harakeh, S. Antimicrobial resistance of Staphylococcus species isolated from Lebanese dairy-based products. East. Mediterr. Health J. 2012, 16, 1221-1225. [CrossRef]

17. Al Omari, S.; Al Mir, H.; Wrayde, S.; Merhabi, S.; Dhaybi, I.; Jamal, S.; Chahine, M.; Bayaa, R.; Tourba, F.; Tantawi, H.; et al. First Lebanese antibiotic awareness week campaign: Knowledge, attitudes and practices towards antibiotics. J. Hosp. Infect. 2019, 101, 475-479. [CrossRef]

18. Al-Mir, H.; Osman, M.; Drapeau, A.; Hamze, M.; Madec, J.-Y.; Haenni, M. WGS analysis of clonal and plasmidic epidemiology of colistin-resistance mediated by mor genes in the poultry sector in Lebanon. Front. Microbiol. 2021, 12. [CrossRef]

19. Al-Mir, H.; Osman, M.; Azar, N.; Madec, J.Y.; Hamze, M.; Haenni, M. Emergence of clinical mcr-1-positive Escherichia coli in Lebanon. J. Glob. Antimicrob. Resist. 2019, 19, 83-84. [CrossRef]

20. Kim, J.; Jeon, S.; Rhie, H.; Lee, B.; Park, M.; Lee, H.; Lee, J.; Kim, S. Rapid detection of extended spectrum $\beta$-lactamase (ESBL) for Enterobacteriaceae by use of a multiplex PCR-based method. Infect. Chemother. 2009, 41, 181-184. [CrossRef]

21. Clermont, O.; Christenson, J.K.; Denamur, E.; Gordon, D.M. The Clermont Escherichia coli phylo-typing method revisited: Improvement of specificity and detection of new phylo-groups: A new E. coli phylo-typing method. Environ. Microbiol. Rep. 2013, 5, 58-65. [CrossRef] [PubMed]

22. Notcovich, S.; DeNicolo, G.; Flint, S.H.; Williamson, N.B.; Gedye, K.; Grinberg, A.; Lopez-Villalobos, N. Biofilm-forming potential of Staphylococcus aureus isolated from clinical mastitis cases in New Zealand. Vet. Sci. 2018, 5, 8. [CrossRef] [PubMed]

23. Cucarella, C.; Tormo, M.Á.; Úbeda, C.; Trotonda, M.P.; Monzón, M.; Peris, C.; Amorena, B.; Lasa, Í.; Penadés, J.R. Role of Biofilm-associated protein Bap in the pathogenesis of bovine Staphylococcus aureus. Infect. Immun. 2004, 72, 2177-2185. [CrossRef] [PubMed]

24. Vitale, M.; Gaglio, S.; Galluzzo, P.; Cascone, G.; Piraino, C.; Di Marco Lo Presti, V.; Alduina, R. Antibiotic resistance profiling, analysis of virulence aspects and molecular genotyping of Staphylococcus aureus isolated in Sicily, Italy. Foodborne. Pathog. Dis. 2018, 15, 177-185. [CrossRef]

25. Magiorakos, A.P.; Srinivasan, A.; Carey, R.B.; Carmeli, Y.; Falagas, M.E.; Giske, C.G.; Harbarth, S.; Hindler, J.F.; Kahlmeter, G.; Olsson-Liljequist, B.; et al. Multidrug-resistant, extensively drug-resistant and pandrug-resistant bacteria: An international expert proposal for interim standard definitions for acquired resistance. Clin. Microbiol. Infect. 2012, 18, 268-281. [CrossRef] [PubMed]

26. El Achkar, S.; Demanche, C.; Osman, M.; Rafei, R.; Ismail, M.B.; Yaacoub, H.; Pinçon, C.; Duthoy, S.; De Matos, F.; Gaudin, C.; et al. Drug-resistant tuberculosis, Lebanon, 2016-2017. Emerg. Infect. Dis. 2019, 25, 564-568. [CrossRef]

27. Osman, M.; Al Bikai, A.; Rafei, R.; Mallat, H.; Dabboussi, F.; Hamze, M. Species distribution and antifungal susceptibility patterns of clinical Candida isolates in North Lebanon: A pilot cross-sectional multicentric study. J. Mycol. Med. 2020, 30, 100986. [CrossRef]

28. Osman, M.; Bidon, B.; Abboud, C.; Zakaria, A.; Hamze, B.; Achcar, M.E.; Mallat, H.; Dannaoui, E.; Dabboussi, F.; Papon, N.; et al. Species distribution and antifungal susceptibility of Aspergillus clinical isolates in Lebanon. Future Microbiol. 2021, 16, 13-26. [CrossRef]

29. Bendary, M.M.; Solyman, S.M.; Azab, M.M.; Mahmoud, N.F.; Hanora, A.M. Characterization of Methicillin Resistant Staphylococcus aureus isolated from human and animal samples in Egypt. Cell. Mol. Biol. 2016, 62, 94-100.

30. El-Ashker, M.; Gwida, M.; Monecke, S.; El-Gohary, F.; Ehricht, R.; Elsayed, M.; Akinduti, P.; El-Fateh, M.; Maurischat, S. Antimicrobial resistance pattern and virulence profile of $S$. aureus isolated from household cattle and buffalo with mastitis in Egypt. Vet. Microbiol. 2020, 240, 108535. [CrossRef] [PubMed]

31. Klibi, A.; Maaroufi, A.; Torres, C.; Jouini, A. Detection and characterization of methicillin-resistant and susceptible coagulase-negative staphylococci in milk from cows with clinical mastitis in Tunisia. Int. J. Antimicrob. Agents 2018, 52, 930-935. [CrossRef] [PubMed]

32. Ben Said, M.; Abbassi, M.S.; Bianchini, V.; Sghaier, S.; Cremonesi, P.; Romano, A.; Gualdi, V.; Hassen, A.; Luini, M.V. Genetic characterization and antimicrobial resistance of Staphylococcus aureus isolated from bovine milk in Tunisia. Lett. Appl. Microbiol. 2016, 63, 473-481. [CrossRef] [PubMed]

33. Cvetnić, L.; Samardžija, M.; Habrun, B.; Kompes, G.; Benić, M. Microbiological monitoring of mastitis pathogens in the control of udder health in dairy cows. Slov. Vet. Res. 2016, 53, 131-140.

34. Burović, J. Isolation of bovine clinical mastitis bacterial pathogens and their antimicrobial susceptibility in the Zenica region in 2017. Vet. Stn. 2020, 51, 47-52. [CrossRef] 
35. Saidi, R.; Cantekin, Z.; Mimoune, N.; Ergun, Y.; Solmaz, H.; Khelef, D.; Kaidi, R. Investigation of the presence of slime production, VanA gene and antiseptic resistance genes in Staphylococci isolated from bovine mastitis in Algeria. Vet. Stn. 2021, 52. [CrossRef]

36. Marzoli, F.; Turchi, B.; Pedonese, F.; Torracca, B.; Bertelloni, F.; Cilia, G.; Cerri, D.; Fratini, F. Coagulase negative staphylococci from ovine bulk-tank milk: Effects of the exposure to sub-inhibitory concentrations of disinfectants for teat-dipping. Comp. Immunol. Microbiol. Infect. Dis. 2021, 76, 101656. [CrossRef]

37. Turchi, B.; Bertelloni, F.; Marzoli, F.; Cerri, D.; Tola, S.; Azara, E.; Longheu, C.M.; Tassi, R.; Schiavo, M.; Cilia, G.; et al. Coagulase negative staphylococci from ovine milk: Genotypic and phenotypic characterization of susceptibility to antibiotics, disinfectants and biofilm production. Small Ruminant. Res. 2020, 183, 106030. [CrossRef]

38. Zecconi, A.; dell'Orco, F.; Rizzi, N.; Vairani, D.; Cipolla, M.; Pozzi, P.; Zanini, L. Cross-sectional study on the prevalence of contagious pathogens in bulk tank milk and their effects on somatic cell counts and milk yield. Italian J. Anim. Sci. 2020, 19, 66-74. [CrossRef]

39. Botrel, M.-A.; Haenni, M.; Morignat, E.; Sulpice, P.; Madec, J.-Y.; Calavas, D. Distribution and antimicrobial resistance of clinical and subclinical mastitis pathogens in dairy cows in Rhône-Alpes, France. Foodborne Pathog. Dis. 2010, 7, 479-487. [CrossRef]

40. Castro, A.; Pereira, J.; Amiama, C.; Lema, J. Mastitis diagnosis in ten Galician dairy herds (NW Spain) with automatic milking systems. Span. J. Agric. Res. 2015, 13, e0504. [CrossRef]

41. Filioussis, G.; Kachrimanidou, M.; Christodoulopoulos, G.; Kyritsi, M.; Hadjichristodoulou, C.; Adamopoulou, M.; Tzivara, A.; Kritas, S.K.; Grinberg, A. Short communication: Bovine mastitis caused by a multidrug-resistant, mcr-1-positive (colistin-resistant), extended-spectrum $\beta$-lactamase-producing Escherichia coli clone on a Greek dairy farm. J. Dairy Sci. 2020, 103, 852-857. [CrossRef] [PubMed]

42. Thomas, V.; de Jong, A.; Moyaert, H.; Simjee, S.; El Garch, F.; Morrissey, I.; Marion, H.; Vallé, M. Antimicrobial susceptibility monitoring of mastitis pathogens isolated from acute cases of clinical mastitis in dairy cows across Europe: VetPath results. Int $J$. Antimicrob. Agents 2015, 46, 13-20. [CrossRef]

43. Ghatak, S.; Singha, A.; Sen, A.; Guha, C.; Ahuja, A.; Bhattacharjee, U.; Das, S.; Pradhan, N.R.; Puro, K.; Jana, C.; et al. Detection of New Delhi metallo-beta-lactamase and extended-spectrum beta-lactamase genes in Escherichia coli isolated from mastitic milk samples. Transbound. Emerg. Dis. 2013, 60, 385-389. [CrossRef]

44. Su, Y.; Yu, C.-Y.; Tsai, Y.; Wang, S.-H.; Lee, C.; Chu, C. Fluoroquinolone-resistant and extended-spectrum $\beta$-lactamaseproducing Escherichia coli from the milk of cows with clinical mastitis in Southern Taiwan. J. Microbiol. Immunol. Infect. 2016, 49, 892-901. [CrossRef] [PubMed]

45. El Moujaber, G.; Osman, M.; Rafei, R.; Dabboussi, F.; Hamze, M. Molecular mechanisms and epidemiology of resistance in Streptococcus pneumoniae in the Middle East region. J. Med. Microbiol. 2017, 66, 847-858. [CrossRef] [PubMed]

46. Reslan, L.; Finianos, M.; Bitar, I.; Moumneh, M.B.; Araj, G.F.; Zaghlout, A.; Boutros, C.; Jisr, T.; Nabulsi, M.; Kara Yaccoub, G.; et al. The emergence of invasive Streptococcus pneumoniae serotype 24F in Lebanon: Complete genome sequencing reveals high virulence and antimicrobial resistance characteristics. Front. Microbiol. 2021, 12. [CrossRef] [PubMed]

47. El Ashkar, S.; Osman, M.; Rafei, R.; Mallat, H.; Achkar, M.; Dabboussi, F.; Hamze, M. Molecular detection of genes responsible for macrolide resistance among Streptococcus pneumoniae isolated in North Lebanon. J. Infect. Public Health 2017, 10, 745-748. [CrossRef]

48. Tian, X.Y.; Zheng, N.; Han, R.W.; Ho, H.; Wang, J.; Wang, Y.T.; Wang, S.Q.; Li, H.G.; Liu, H.W.; Yu, Z.N. Antimicrobial resistance and virulence genes of Streptococcus isolated from dairy cows with mastitis in China. Microb. Pathog. 2019, 131, 33-39. [CrossRef]

49. Mileva, R.; Karadaev, M.; Fasulkov, I.; Petkova, T.; Rusenova, N.; Vasilev, N.; Milanova, A. Oxytetracycline Pharmacokinetics After Intramuscular Administration in Cows with Clinical Metritis Associated with Trueperella pyogenes Infection. Antibiotics 2020, 9, 392. [CrossRef]

50. Denamiel, G.; Llorente, P.; Carabella, M.; Rebuelto, M.; Gentilini, E. Anti-microbial susceptibility of Streptococcus spp. isolated from bovine mastitis in Argentina. J. Vet. Med. B Infect. Dis. Vet. Public Health 2005, 52, 125-128. [CrossRef]

51. Petrovski, K.R.; Grinberg, A.; Williamson, N.B.; Abdalla, M.E.; Lopez-Villalobos, N.; Parkinson, T.J.; Tucker, I.G.; Rapnicki, P. Susceptibility to antimicrobials of mastitis-causing Staphylococcus aureus, Streptococcus uberis and Str. dysgalactiae from New Zealand and the USA as assessed by the disk diffusion test. Aust. Vet. J. 2015, 93, 227-233. [CrossRef]

52. Osman, M.; Kamal-Dine, K.; El Omari, K.; Rafei, R.; Dabboussi, F.; Hamze, M. Prevalence of Staphylococcus aureus methicillinsensitive and methicillin-resistant nasal carriage in food handlers in Lebanon: A potential source of transmission of virulent strains in the community. Access Microbiol. 2019. [CrossRef] [PubMed]

53. Rafei, R.; Hawli, M.; Osman, M.; Dabboussi, F.; Hamze, M. Distribution of emm types and macrolide resistance determinants among group A streptococci in the Middle East and North Africa. J. Glob. Antimicrob. Resist. 2020. [CrossRef] [PubMed]

54. Rafei, R.; Hawli, M.; Osman, M.; Khelissa, S.; Salloum, T.; Dabboussi, F.; Tokajian, S.; Hamze, M. Molecular epidemiology of nonpharyngeal group A streptococci isolates in northern Lebanon. Future Microbiol. 2020, 15, 1555-1569. [CrossRef]

55. Moghnieh, R.; Araj, G.F.; Awad, L.; Daoud, Z.; Mokhbat, J.E.; Jisr, T.; Abdallah, D.; Azar, N.; Irani-Hakimeh, N.; Balkis, M.M.; et al. A compilation of antimicrobial susceptibility data from a network of 13 Lebanese hospitals reflecting the national situation during 2015-2016. Antimicrob. Resist. Infect. Control. 2019, 8, 41. [CrossRef]

56. Cvetnić, L.; Samardžija, M.; Duvnjak, S.; Habrun, B.; Cvetnić, M.; Jaki Tkalec, V.; Đuričić, D.; Benić, M. Multi Locus Sequence Typing and spa typing of Staphylococcus aureus isolated from the milk of cows with subclinical mastitis in Croatia. Microorganisms 2021, 9, 725. [CrossRef] 
57. Elias, L.; Balasubramanyam, A.S.; Ayshpur, O.Y.; Mushtuk, I.U.; Sheremet, N.O.; Gumeniuk, V.V.; Musser, J.M.B.; Rogovskyy, A.S. Antimicrobial susceptibility of Staphylococcus aureus, Streptococcus agalactiae, and Escherichia coli isolated from mastitic dairy cattle in Ukraine. Antibiotics 2020, 9, 469. [CrossRef]

58. Hmede, Z.; Kassem, I.I. The colistin resistance gene $m c r-1$ is prevalent in commensal Escherichia coli isolated from preharvest poultry in lebanon. Antimicrob. Agents Chemother. 2018, 62. [CrossRef]

59. Coura, F.M.; Diniz Sde, A.; Silva, M.X.; Mussi, J.M.; Barbosa, S.M.; Lage, A.P.; Heinemann, M.B. Phylogenetic Group Determination of Escherichia coli isolated from animals samples. Sci. World J. 2015, 2015, 258424. [CrossRef]

60. Kempf, F.; Slugocki, C.; Blum, S.E.; Leitner, G.; Germon, P. Genomic comparative study of bovine mastitis Escherichia coli. PLoS ONE 2016, 11, e0147954. [CrossRef]

61. Ghanbarpour, R.; Oswald, E. Phylogenetic distribution of virulence genes in Escherichia coli isolated from bovine mastitis in Iran. Res. Vet. Sci. 2010, 88, 6-10. [CrossRef]

62. Tomazi, T.; Coura, F.M.; Gonçalves, J.L.; Heinemann, M.B.; Santos, M.V. Antimicrobial susceptibility patterns of Escherichia coli phylogenetic groups isolated from bovine clinical mastitis. J. Dairy Sci. 2018, 101, 9406-9418. [CrossRef]

63. Nuesch-Inderbinen, M.; Kappeli, N.; Morach, M.; Eicher, C.; Corti, S.; Stephan, R. Molecular types, virulence profiles and antimicrobial resistance of Escherichia coli causing bovine mastitis. Vet. Rec. Open 2019, 6, e000369. [CrossRef]

64. Zhang, D.; Zhang, Z.; Huang, C.; Gao, X.; Wang, Z.; Liu, Y.; Tian, C.; Hong, W.; Niu, S.; Liu, M. The phylogenetic group, antimicrobial susceptibility, and virulence genes of Escherichia coli from clinical bovine mastitis. J. Dairy Sci. 2018, 101, 572-580. [CrossRef] [PubMed]

65. Todorovic, D.; Velhner, M.; Grego, E.; Vidanovic, D.; Milanov, D.; Krnjaic, D.; Kehrenberg, C. Molecular characterization of multidrug-resistant Escherichia coli isolates from bovine clinical mastitis and pigs in the Vojvodina province, Serbia. Microb. Drug Resist. 2018, 24, 95-103. [CrossRef]

66. Keane, O.M. Genetic diversity, the virulence gene profile and antimicrobial resistance of clinical mastitis-associated Escherichia coli. Res. Microbiol. 2016, 167, 678-684. [CrossRef] [PubMed]

67. Yang, F.; Zhang, S.; Shang, X.; Wang, L.; Li, H.; Wang, X. Characteristics of quinolone-resistant Escherichia coli isolated from bovine mastitis in China. J. Dairy Sci. 2018, 101, 6244-6252. [CrossRef] [PubMed]

68. Szweda, P.; Schielmann, M.; Milewski, S.; Frankowska, A.; Jakubczak, A. Biofilm production and presence of ica and bap genes in Staphylococcus aureus strains isolated from cows with mastitis in the eastern Poland. Pol. J. Microbiol. 2012, 61, 65-69. [CrossRef]

69. Prenafeta, A.; Sitjà, M.; Holmes, M.A.; Paterson, G.K. Short communication: Biofilm production characterization of mecA and mecC methicillin-resistant Staphylococcus aureus isolated from bovine milk in Great Britain. J. Dairy Sci. 2014, 97, 4838-4841. [CrossRef]

70. Fitzgerald, J.R.; Monday, S.R.; Foster, T.J.; Bohach, G.A.; Hartigan, P.J.; Meaney, W.J.; Smyth, C.J. Characterization of a putative pathogenicity island from bovine Staphylococcus aureus encoding multiple superantigens. J. Bacteriol. 2001, 183, 63-70. [CrossRef] 